\title{
UJI PERFORMA BATERAI UNTUK BEBAN UTAMA MOTOR DC PERAHU PULANG HARI
}

\author{
BATTERY PERFORMANCE TEST FOR MAIN LOAD OF “ONE DAY FISHING” BOAT
}

\author{
Donal Daniel dan Daud S.A. Sianturi \\ Pusat Pengkajian dan Perekayasaan Teknologi Kelautan Perikanan \\ Badan Penelitian dan Pengembangan Kelautan dan Perikanan \\ e-mail: donald3th1975@yahoo.com
}

Diterima tanggal: 28 Mei 2013, diterima setelah perbaikan tanggal: 31 Juli 2013, disetujui tanggal: 1 Agustus 2013

\begin{abstract}
ABSTRAK
Perahu nelayan "pulang hari" rancangan Pusat Pengkajian dan Perekayasaan Teknologi Kelautan dan Perikanan (P3TKP) telah berhasil dibuat untuk memenuhi keinginan nelayan akan transportasi yang aman dan ekonomis. Pemanfaatan motor listrik dimaksudkan agar nelayan terbebas dari bahan bakar minyak (BBM) dan sebagai upaya menjaga lingkungan perairan dari buangan limbah BBM. Dalam penelitian ini penulis melakukan pengamatan terhadap laju pengambilan energi dari aki ke beban utama dengan lima variasi baling-baling sehingga dapat diprediksi jumlah kebutuhan aki agar perahu dapat beroperasi dalam 8 sampai 9 jam per hari operasi. Dari uji kolam menggunakan motor DC 370 watt dan 2 buah aki 100 Ah, aki telah berhasil menyuplai energi ke beban utama motor DC dengan pengambilan daya (recharge) adalah 2 volt tiap 10 menit dengan arus listrik (ampere) berubah-ubah pada kondisi kecepatan (rpm) yang berubah-ubah pula.
\end{abstract}

Kata kunci: perahu nelayan, motor DC, lingkungan laut

\section{ABSTRACT}

The fishing boat "one day fishing” designed by (P3TKP) has been successfully made to meet the need of fishermen of a safely and economical transportation. Utilization of electric motors is intended to fishermen freed from fuel and as an effort to participate in maintaining the marine environment from waste fuel. In this study the authors make the observation of the rate of energy recharge (volts and amperes) by use of different propeller so it can be predicted the amount of battery so that the boat can operate for 8 to 9 hours of operation per day. From the tunnel experiment using the 370 Watts of a motor power and 2 batteries of $100 \mathrm{Ah}$, the system has been successfully supplying energy to the main load of the electric motor. The data shows that average power recharge from the battery is 2 volts every 10 minutes and the electric current is vary to the load and speed (rpm) conditions.

Keywords: fishing boat, motor DC, marine environment

\section{PENDAHULUAN}

Perahu atau kapal merupakan moda transportasi utama nelayan dalam menangkap ikan. Kapalkapal nelayan yang kita kenal saat ini masih sepenuhnya menggunakan BBM sebagai energi penggerak mesin - mesin kapal. Ketergantungan ini menyebabkan nelayan tidak mempunyai pilihan selain membeli BBM agar mereka bisa melaut meskipun dengan harga yang tinggi. Di tengah kondisi tersebut biasanya nelayan menyiasati dengan memodifikasi mesin kapal agar dapat menggunakan campuran bahan bakar dengan perbandingan tertentu (Mustaín, 2009). Perilaku nelayan dengan menggunakan bahan bakar campur dapat mengakibatkan kerusakan mesin jangka pendek, dan dampaknya pada meningkatnya operasional cost. Disamping itu, perilaku nelayan yang sering membuang sisa-sisa bahan bakar juga sangat berpotensi menyebabkan pencemaran sehingga menurunkan kualitas perairan di pelabuhan (Siaka, 2008).

Berdasarkan kenyataan tersebut, salah satu solusi agar ketergantungan terhadap BBM dapat dikurangi adalah dengan memberikan pilihan alat 
penggerak perahu berupa motor listrik DC sebagai penggerak perahu yang fungsinya sama dengan motor bakar (diesel) (Mustain, 2009).

Prinsip dari motor listrik DC adalah mengubah energi listrik menjadi energi mekanik putaran untuk memutar poros yang terhubung ke balingbaling perahu agar dapat bergerak pada kecepatan yang diinginkan (Murdijanto, 2005).

Motor DC memerlukan suplai tegangan yang searah pada kumparan medan untuk diubah menjadi energi mekanik. Dengan memberikan beda tegangan pada kedua terminal, motor akan berputar pada satu arah, dan bila polaritas dari tegangan tersebut dibalik maka arah putaran motor akan terbalik pula. Polaritas dari tegangan yang diberikan pada dua terminal menentukan arah putaran motor sedangkan besar dari beda tegangan pada kedua terminal menentukan kecepatan motor. Sebelum kita memilih sebuah motor maka perlu mengetahui berapa besar beban yang dipikul oleh motor.

Beban motor mengacu kepada keluaran tenaga putar (torque) sesuai dengan kecepatan yang diperlukan. Beban motor listrik dikategorikan ke dalam beban dengan variable torque yaitu beban dengan torque yang bervariasi dengan kecepatan operasi (Sadiku, 2009).

Dengan adanya beban ini, maka dalam motor kemungkinan terjadi kehilangan energi sehingga berhubungan erat dengan daya $(\mathrm{P})$ yang diterima dan dihasilkan. Sehingga didapat besar efisiennsi motor, yaitu seberapa maksimal energi yang dapat diubah (dari listrik ke mekanik).

Oleh karena itu pemilihan motor DC harus mampu menggerakkan perahu pada kecepatan yang diinginkan setelah dikurangi rugi-rugi dan faktor efisiensi mekanis yang terjadi pada susunan sistem propulsi (pemakaian gearbox, dll). Atau cukup diatasi oleh 80 - 85\% daya motor (engine rated power) dan pada kisaran $100 \%$ putaran motor (engine rated speed). Inilah daya motor yang akan di install (Adjie, 2009). Ilustrasinya seperti Gambar 1.

Hambatan perahu di air dan rugi-rugi yang telah disebutkan mempengaruhi besaran beban motor. Jumlah totalnya harus diketahui untuk menentukan kapasitas/kebutuhan baterai karena berhubungan dengan arus listrik yang dihasilkan pada torsi yang dibutuhkan motor untuk menggerakkan perahu.

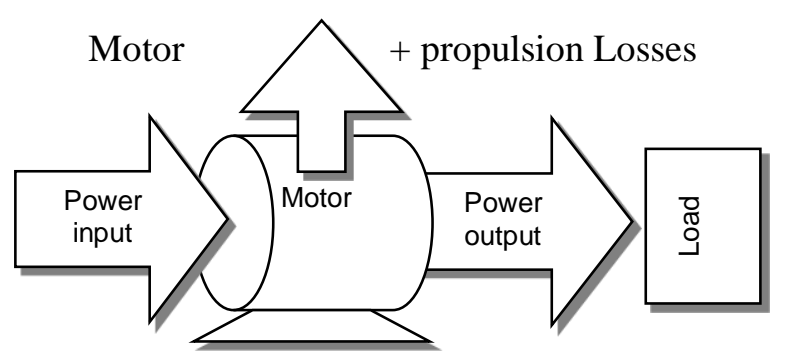

Gambar 1. Ilustrasi rugi-rugi pada motor Figure 1. Motor losses illustration

Penentuan torsi merupakan hubungan antara arus pada penghantar, medan magnet dan arah gaya sehingga torsi berhubungan dengan arus yang disedot dari baterai/aki. Beban motor sebaiknya sekecil mungkin agar sedotan arus listrik (discharge) dari baterai tidak berlebihan, biasanya dibatasi tidak melebihi 50\% dari kapasitas totalnya (Togan, 2010). Atau DOD (deep of discharge) baterai adalah sebesar $70 \%$ dari kapasitas total baterai, artinya isi baterai $70 \%$ ini akan habis dalam kurun waktu (jam) dimana waktu yang diperlukan perahu wisata untuk jarak tempuh $(\mathrm{km}$ atau mil laut) pada kecepatan yang diinginkan (Sudiyono dan Antoko, 2008).

Prinsip DOD adalah suatu ketentuan yang membatasi tingkat kedalaman discharge maksimum yang dapat diberlakukan pada baterai. Pengaturan DOD berperan dalam menjaga usia pakai (life time) dari baterai tersebut. Semakin dalam DOD yang diberlakukan pada suatu baterai, maka semakin pendek pula usia pakai dari baterai tersebut (MIT Electric Vehicle Team, 2008).

Oleh karena itu penggunaan baterai Deep Cycle, dianjurkan untuk DOD yang dalam dan terusmenerus, karena dapat discharge sejumlah arus listrik secara konstan dalam waktu yang lama. Umumnya baterai deep cycle dapat discharge sampai dengan $80 \%$ kapasitas baterai. Dengan perencanaan kapasitas dan maintenance yang baik, baterai jenis ini dapat bertahan lama hingga kurang lebih 10 tahun.

DOD yang diberlakukan pada baterai yang akan digunakan pada sistem kali ini adalah sebesar $70 \%$. Laju penurunan discharge baterai sangat tergantung arus listrik yang dibutuhkan motor untuk menghasilkan tenaga dorong pada kecepatan 
yang diinginkan (Daniel, 2009). Dalam rancangan sistem propulsi listrik ini, perahu nelayan harian diasumsikan beroperai selama sembilan jam. Sehingga dari penelitian ini hasil akhirnya adalah untuk memprediksi berapa jumlah baterai yang ideal untuk memenuhi lama waktu perahu beroperasi.

\section{BAHAN DAN METODE}

Bahan yang digunakan dalam penelitian ini adalah:

a. Desain perahu pulang hari hasil pengolahan program Maxsurf.

b. Motor listrik 370 Watt 24 VDC

c. Susunan sistem propulsi

d. Baling-baling diamater 16, 20, 22, 25, $28 \mathrm{~cm}$

e. Baterai kering @100 Ah 1 buah.

Alat ukur yang digunakan adalah:

a. Pengukur RPM motor

b. Pengukur tegangan listrik (V) dan Arus listrik (A)

c. Stop Watch

Metode yang digunakan pada penelitian ini adalah: Pengujian performa baterai bila baling-baling motor listrik DC dalam keadaan tercelup, untuk menilai kemampuan baterai (waktu,T) menyuplai arus listrik ke motor DC, dengan asumsi:

- Hasil perhitungan waktu ini akan menjadi acuan banyaknya baterai yang harus dibawa.

- Perhitungan hambatan perahu akan menjadi acuan besaran daya motor yang diperlukan untuk membawa perahu pergi - pulang pada kecepatan yang diinginkan agar tercapai waktu 9 (sembilan) jam waktu operasional kapal.

Rancangan uji cobanya:

a. Baling-baling pada rancangan sistem propulsi dicelup seluruhnya dengan kemiringan poros/as terhadap muka air 5 derajat (Gambar 4).

b. Motor DC di running pada 1300 RPM penuh dan dilakukan pengambilan data antara lain: perubahan tegangan baterai $(\mathrm{V})$, perubahan arus listrik (A), tiap 10 menit. DOD baterai sebesar $70 \%$ atau kapasitas baterai sisa $30 \%$ pada kisaran $100 \%$.

c. Pengambilan data laju pemakaian arus listrik dari baterai dilakukan setelah RPM motor optimal (stabil). Pengambilan data dilakukan pada 5 (lima) diameter baling-baling (Gambar $6)$. d. Waktu yang dibutuhkan untuk menghabiskan (recharge) baterai hingga tersisa 30\% adalah gambaran kemampuan baterai terpasang untuk menyediakan energi listrik bagi beban dari motor DC yang dipakai.

e. Kemudian dari hasil tersebut dapat diprediksi jumlah baterai yang dibutuhkan untuk memenuhi power input motor, dengan cara merangkai hubungan seri baterai untuk memperoleh amper-jam total yang paling optimal agar perahu dapat pergi - pulang.

Rancangan sistem propulsinya sesuai dengan Gambar 2.

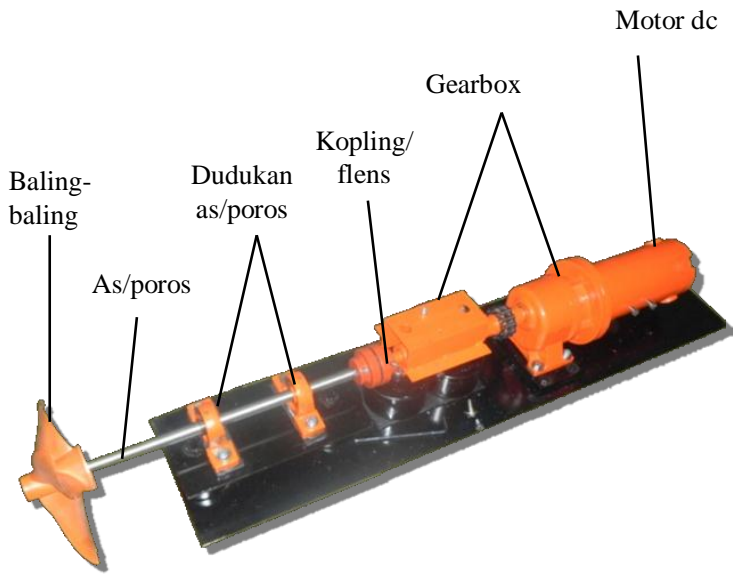

Gambar 2. Susunan sistem propulsi Figure 2. Propulsion system arrangement

Kondisi pencelupan baling-baling seperti Gambar 3.

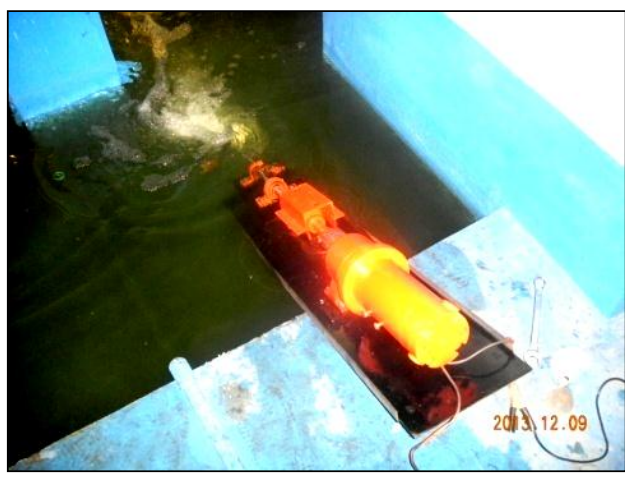

Gambar 3. Pengujian motor di kolam Figure 3. Motor test arrangement

Pengukuran kapasitas baterai (aki) seperti pada Tabel 1. 
Tabel 1. Tabel pengukuran daya motor DC Table 1. Input data table

Diameter Baling-baling:

\begin{tabular}{cccc}
\hline No. & $\begin{array}{c}\text { Tegangan } \\
(\mathrm{V})\end{array}$ & $\begin{array}{c}\text { Arus } \\
(\mathrm{I})\end{array}$ & $\begin{array}{c}\text { Daya } \\
(\mathrm{P}=\mathrm{V} x \mathrm{I})\end{array}$ \\
\hline 1. & & &
\end{tabular}

f. Pengukuran kapasitas baterai (battery sizing) dan daya recharge.

Untuk menjamin kontinuitas pasokan listrik ke motor DC maka jumlah dan kapasitas baterai (aki) harus cukup agar perahu dapat pergi - pulang. Selanjutnya bagaimana baterai tersebut dirangkai (jenis rangkaian yang digunakan, apakah seri, pararel atau seri-pararel).

\section{HASIL DAN PEMBAHASAN}

Sistem propulsi pada Gambar 2 adalah sistem yang diuji untuk desain perahu pada Gambar 4. Sebagai asumsi hambatan yang dihitung adalah dari desain perahu yang dibuat dengan program Maxsurf.

\subsection{Perhitungan hambatan perahu}

Untuk mengetahui daya motor listrik DC sebagai penggerak perahu, maka hambatan perahu hasil perhitungan sebagai titik tolak penentuan daya motor.

Tabel 2. Karakteristik perahu nelayan pulang hari di Indonesia

Table 2. One day fishing boat characteristics in Indonesian onshore

\begin{tabular}{ll} 
& Indonesian onshore \\
\hline Panjang perahu & $7-9$ meter \\
\hline Alat tangkap & Pancing ulur/tangan \\
\hline Jumlah nelayan & $3-4$ orang \\
\hline $\begin{array}{l}\text { Perlengkapan } \\
\text { perahu }\end{array}$ & Cadik (sayap keseimbangan) \\
\hline Mesin penggerak & $\begin{array}{l}\text { Diesel 5,5 - 8,5 PK system } \\
\text { pasang-lepas }\end{array}$ \\
\hline Muatan & $\begin{array}{l}\text { Es curah di dalam drum } \\
\text { plastik kap. 200 liter }\end{array}$ \\
\hline Bahan bakar & Solar 10-15 Liter \\
\hline $\begin{array}{l}\text { Ongkos } \\
\text { operasional/trip }\end{array}$ & Rp. 300.000,00-500.000,00 \\
\hline
\end{tabular}

Desain perahu memakai metode coba-coba (trial and error) dan perahu pembanding. Beberapa perahu hasil pengamatan di pelabuhan dan contohcontoh yang diperoleh dari dokumentasi dan pengalaman tim penelitian, maka perahu-perahu nelayan pulang hari di pesisir Indonesia umumnya memiliki karakteristik yang sama sebagaimana tercantum pada Tabel 2. (Daniel et al., 2007).

Ukuran utama perahu yang ditetapkan adalah sebagai berikut.

- Panjang keseluruhan (Loa) : 7,00 m

- Lebar keseluruhan (B) $\quad: 1,20 \mathrm{~m}$

- Tinggi pada tengah (D) $\quad: 0,70 \mathrm{~m}$

- Sarat (T) :0,30 m

- Daya motor listrik : $370 \mathrm{Watt}$

Dari ukuran utama tersebut kemudian digambar pada program Maxsurf untuk dianalisis hambatannya (Gambar 4).

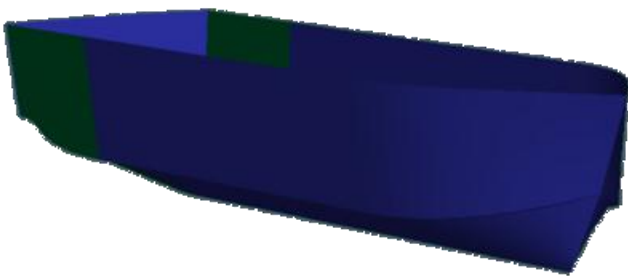

Gambar 4. Gambar perspektif perahu nelayan

Figure 4. The perspective of "oneday fishing" boat

Hambatan perahu dihitung pada beberapa variasi kecepatan seperti pada Tabel 3 .

Tabel 3. Hambatan perahu yang terjadi pada beberapa kecepatan

Table 3. Boat resistance at speed range

\begin{tabular}{rrr}
\hline & \multicolumn{2}{c}{ Tahanan } \\
\cline { 2 - 3 } Speed (kn) & Newton $(\mathrm{N})$ & Watt $(\mathrm{W})$ \\
\hline 1.75 & 15.71 & 15.71 \\
\hline 2 & 20.21 & 23.1 \\
\hline 3 & 46.99 & 80.58 \\
\hline 4 & 98.16 & 224.43 \\
\hline 5 & 192.81 & 551.05 \\
\hline 6 & 264.7 & 907.82 \\
\hline 7 & 524.25 & 2097.66 \\
\hline 8 & 850.84 & 3890.75 \\
\hline 9 & 1200 & 6173.32 \\
\hline 10 & 1455.27 & 8318.42 \\
\hline
\end{tabular}

Hubungan antara kecepatan (knot) dengan daya (Watt) dan hambatan perahu (Newton) ditunjukkan dengan grafik Gambar 5 berikut ini. 


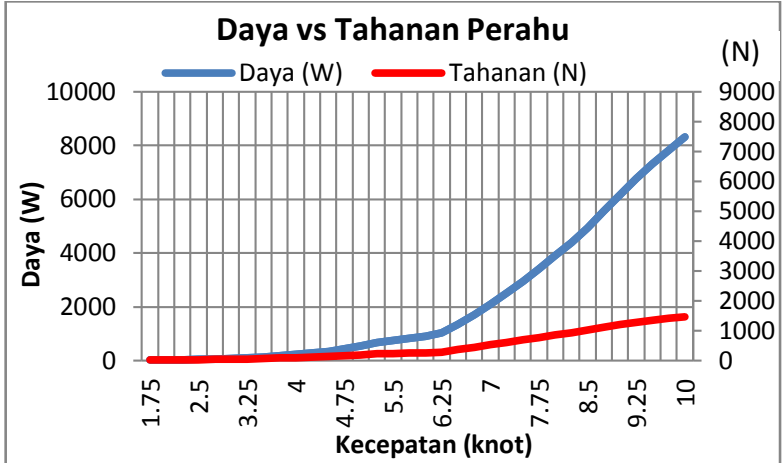

Gambar 5. Hubungan tahanan (Newton) dan daya motor (watt) vs kecepatan perahu (knot)

Figure 5. Boat resistance and power versus speed

Nilai watt pada Tabel 3. adalah sebagai acuan di dalam melihat kelayakan motor DC terpasang.

Tabel 4. Data kesimpulan perahu dari hasil pengolahan Maxsurf.

Table 4. Maxsurf data

\begin{tabular}{|c|c|}
\hline Measurement & Value Units \\
\hline Displacement & $934.88 \mathrm{~kg}$ \\
\hline Volume & $0.912 \mathrm{~m}^{\wedge} 3$ \\
\hline Draft to Baseline & $0.3 \mathrm{~m}$ \\
\hline Immersed depth & $0.3 \mathrm{~m}$ \\
\hline Lwl & $6.613 \mathrm{~m}$ \\
\hline Beam wl & $0.837 \mathrm{~m}$ \\
\hline WSA & $7.039 \mathrm{~m}^{\wedge} 2$ \\
\hline Max cross sect area & $0.162 \mathrm{~m}^{\wedge} 2$ \\
\hline Waterplane area & $5.129 \mathrm{~m}^{\wedge} 2$ \\
\hline $\mathrm{Cp}$ & 0.849 \\
\hline $\mathrm{Cb}$ & 0.549 \\
\hline $\mathrm{Cm}$ & 0.647 \\
\hline Cwp & 0.927 \\
\hline
\end{tabular}

\subsection{Perhitungan kapasitas baterai}

Untuk dapat mensuplai kebutuhan daya motor listrik DC selama perahu beroperasi (8 jam/hari), diperlukan baterai dengan kapasitas yang sesuai dengan kebutuhan beban. Analisis bebannya adalah sebagai berikut:

Diketahui daya motor listrik terpasang 370 watt. Motor listrik akan dipakai selama 8 jam, maka total energi listrik selama $8 \mathrm{jam} / 1$ hari adalah sebesar

$370 \mathrm{~W} \times 8$ jam $=2960 \mathrm{Wh}$
Bentuk susunan transmisi poros pada kapal adalah Prime mover, reduction gear dan terakhir balingbaling, sehingga nilai efesiensi gearbox yang dipakai untuk bentuk susunan di atas adalah $98 \%$ (Adjie, 2009).

$$
\begin{aligned}
\mathrm{Pm} & =370 \mathrm{Watt} / 0,98 \\
& =377,55 \mathrm{Watt}
\end{aligned}
$$

Nilai ini kemudian ditambah 10-15\% engine rated power nya pada kisaran $100 \%$ engine rated speed. Penambahan engine rated power digunakan untuk menentukan besarnya kebutuhan daya motor yang harus di instal di kapal sehingga kapal beroperasi dengan kecepatan servis (Adjie, 2009).

Sehingga,

$\mathrm{Pm} \quad=377,55 / 0,85$

$$
=444,1764 \mathrm{Watt}
$$

Maka,

Total kebutuhan energi listrik selama 8 jam/1 hari berubah sebesar

$444,1764 \times 8$ jam $\quad=3553 \mathrm{Wh}$

Nilai inilah yang dipakai untuk menghitung kapasitas (Ah) dari baterai, dilakukan perhitungan sebagai berikut:

$P D C=V R M S \times I R M S \times$ Power Factor

dan

$E A C=V R M S \times I R M S \times$ Power Factor $\times t \ldots$ dengan:

P DC = Kebutuhan Daya Motor (Watt)

E AC = Kebutuhan Energi (Wh)

V RMS = Tengangan Sistem (24 V)

I RMS = Arus listrik yang disuplai (Ah)

Power Factor = Faktor daya beban $(0,9)$

$\mathrm{t} \quad=$ Waktu (Jam)

Nilai Amper Hour $(8$ jam $)=$

$\mathrm{I} \quad=\mathrm{P} /(\mathrm{V} \times \mathrm{PF})$

$=3553 /(24 \times 0,9)$

$=164,49 \mathrm{Ah}$

Menurut "A guide to understanding battery specifications", kapasitas baterai yang dapat disedot (discharge) merupakan nilai yang dihitung terhadap kapasitas maksimumnya. Persentasi discharge setidaknya $80 \%$ dari DOD sebuah baterai deep cycle (MIT Electric Vehicle Team, 2008). 
Dalam penelitian ini DOD yang digunakan sebagai nilai discharge adalah sebesar $70 \%$.

$$
\begin{aligned}
& \text { maka nilai Ah yang dipakai } \\
& \begin{aligned}
\mathrm{I} \quad & =164,49 / 0,3 \\
& =548,3 \mathrm{Ah}
\end{aligned}
\end{aligned}
$$

Jadi kapasitas minimal yang harus dimiliki oleh baterai adalah sebesar 548,3 Ah, untuk melayani kebutuhan energi 3553 Watt-Hour selama 8 jam. Nilai ini adalah beban motor listrik selama 8 jam tanpa beban dari baling-baling. Untuk memperoleh nilai sebenarnya maka dilakukan uji motor terpasang baling-baling seperti berikut ini.

\subsection{Hasil pengujian motor}

Tahap uji kolam dilakukan untuk melihat kemampuan motor listrik memutar baling-baling.

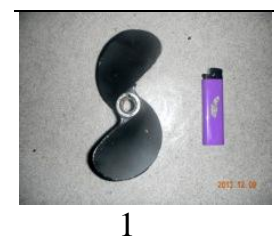

Tipe
Diameter
Jumlah
daun

pitch
Propeller
$16 \mathrm{~cm}$
2

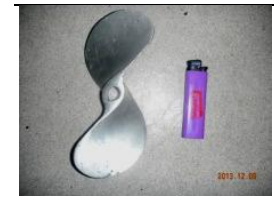

$\begin{array}{lll}\text { Tipe } & : & \text { pitch } \\ & : & \text { Propeller } \\ \text { Diameter } & : & 20 \mathrm{~cm} \\ \text { Jumlah } & & 2\end{array}$

2 daun

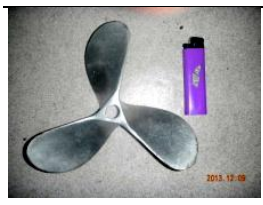

Tipe : pitch : Propeller Diameter : $22 \mathrm{~cm}$ Jumlah 3

3 daun

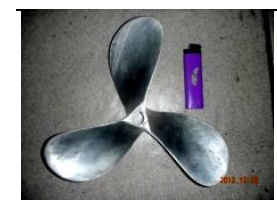
Tipe
Diameter
Jumlah
daun 4

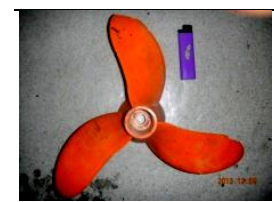

$\begin{array}{lll}\text { Tipe } & : & \text { pitch } \\ & : & \text { Propeller } \\ \text { Diameter } & : & 28 \mathrm{~cm} \\ \text { Jumlah } & & 3 \\ \text { daun } & & \end{array}$

Gambar 6. Variasi baling-baling uji coba. Figure 6. Propeller sample test
Jumlah baterai yang dipakai adalah 1 buah kapasitas 100 Ah. Baling-baling yang digunakan terdiri atas 5 variasi diameter seperti Gambar 6 .

\section{Baling-baling no. 1}

Pengukuran daya motor menggunakan balingbaling nomor 1 selama 3 jam 48 menit pada putaran konstan (1500 rpm). Pengukuran dimulai pada 10.00. memperlihatkan penurunan tegangan aki rata-rata 0,1 Volt setiap 10 menit hingga 13.20. Penurunan yang tajam pada 13.40 dan 13.50 sebesar 2 volt. Jika diambil tren grafik pada Gambar 7 dapat disimpulkan bahwa setelah 10 Volt atau 13.35 dan seterusnya penurunan kapasitas aki cenderung menurun drastis (drop) sampai mencapai tegangan 7 Volt pada 13.48. Hal ini berarti dalam kurun 15 menit penurunnya adalah 3 Volt. Batas DOD baterai 30\% yang harus disisakan agar tidak cepat rusak. Penurunan drastis dapat disebabkan tipe dan kualitas aki yang digunakan tidak sesuai dari yang seharusnya menggunakan aki deep cycle, padahal karakteristik kerja motor listrik adalah discharge tinggi, artinya dijalankan pada putaran maksimum sehingga arus listrik yang terjadi sangat cepat.

\section{Baling-baling no. 2}

Pengukuran daya motor menggunakan balingbaling nomor 2 selama 10 jam pada putaran konstan (1400 rpm) mengalami kelebihan waktu (over recharge). Pengukuran dimulai pada 14.10. memperlihatkan penurunan tegangan aki rata-rata 0,1 Volt setiap 10 menit hingga 19.30 baterai sisa 9 Volt. Selanjutnya kapasitas baterai berkurang ratarata sebesar 1 Volt/10 menit hingga tinggal 1 Volt pada pukul 01.00 ini hari. Batas DOD baterai 30\% yang harus disisakan sebenarnya pada pukul 19.40 dimana kapasitas baterai tersisa 7,96 Volt.

\section{Baling-baling no. 3}

Pengukuran daya motor menggunakan balingbaling nomor 3 selama 6 jam pada putaran konstan (1300 rpm). Pengukuran dimulai pada 9.43. memperlihatkan penurunan tegangan aki rata-rata 0,1 Volt setiap 10 menit hingga 11.50 . selanjutnya penurunan rata-rata sebesar 1 Volt/10 menit 
dimulai pukul 12.00 hingga 15.30. Batas DOD baterai $30 \%$ yang harus disisakan sebenarnya pada pukul 12.10 dimana kapasitas baterai tersisa 7,79 Volt.

\section{Baling-baling no. 4}

Pengukuran daya motor menggunakan balingbaling nomor 4 selama 3 jam pada putaran konstan (1000 rpm). Pengukuran dimulai pada 15.42. memperlihatkan penurunan tegangan aki rata-rata 0,3 Volt setiap 10 menit hingga 17.50. Batas DOD baterai $30 \%$ yang harus disisakan agar tidak cepat rusak terjadi hingga pukul 18.00 dimana kapasitas baterai tersisa kurang lebih 10 Volt.

\section{Baling-baling no. 5}

Pengukuran daya motor menggunakan balingbaling nomor 5 selama 5 jam pada putaran konstan (600 rpm). Pengukuran dimulai pada 11.10. memperlihatkan penurunan tegangan aki rata-rata 2 Volt setiap 10 menit hingga 14.30 kemudian naik lagi ke 11,98 Volt pada pukul 14.40 dan berkurang lagi rata-rata 1 Volt/10 menit hingga ke pukul 16.10. Batas DOD baterai $30 \%$ yang harus disisakan agar baterai tidak cepat rusak terjadi hingga pukul 15.50 dimana kapasitas baterai tersisa kurang lebih 7,5 Volt. Penurunan kapasitas baterai dapat dilihat pada gambar-gambar berikut ini.

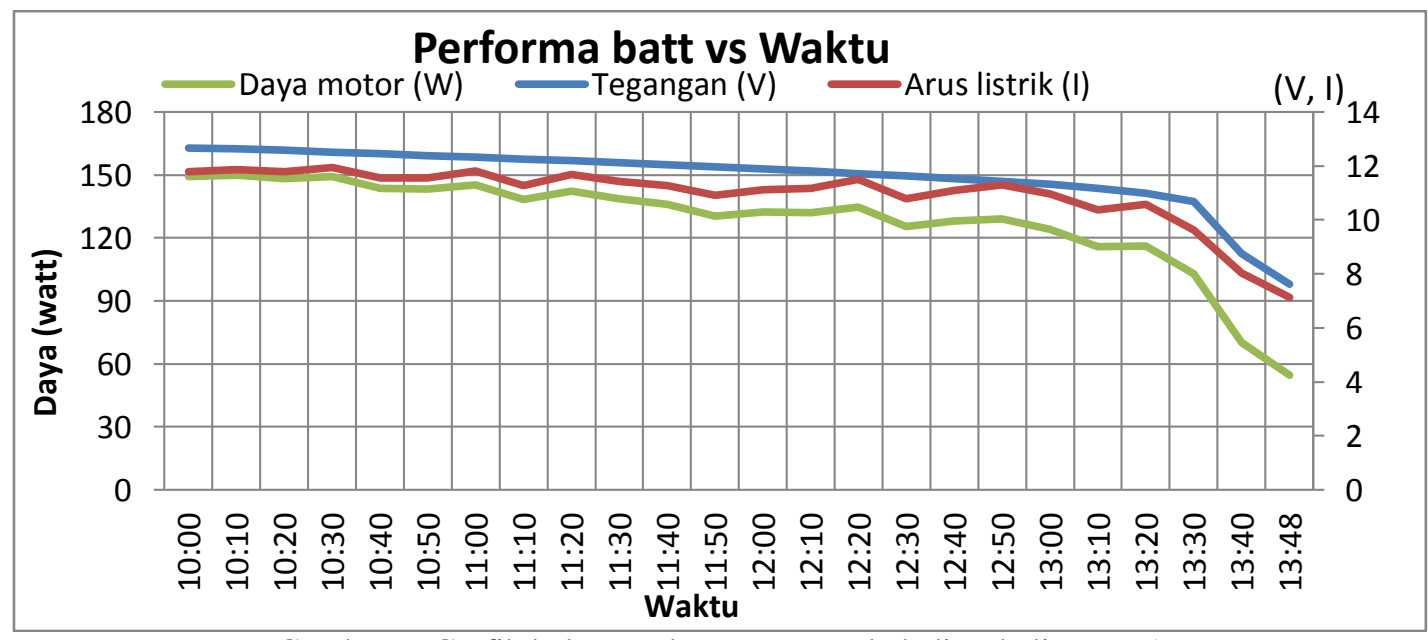

Gambar 7. Grafik keluaran daya motor pada baling-baling no. 1

Figure 7. Motor power output (watts) propeller no.1

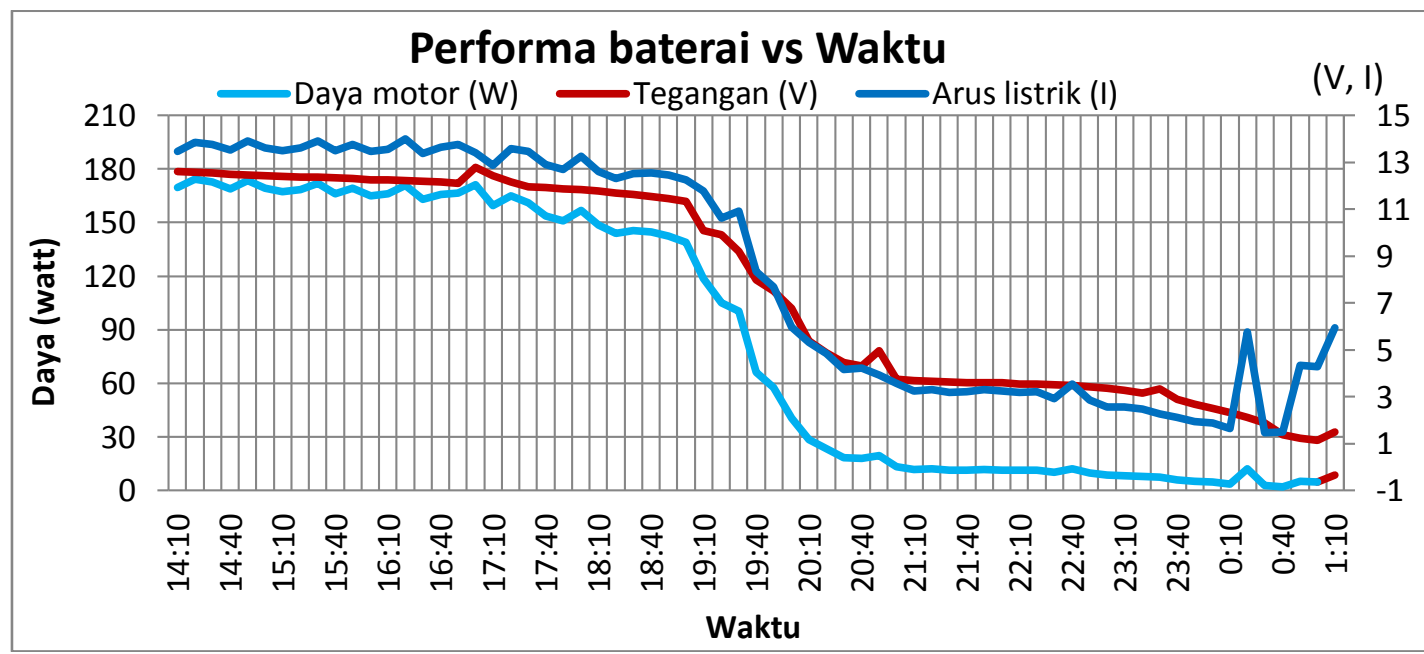

Gambar 8. Grafik keluaran daya motor pada baling-baling no. 2

Figure 8. Motor power output (watts) propeller no. 2 


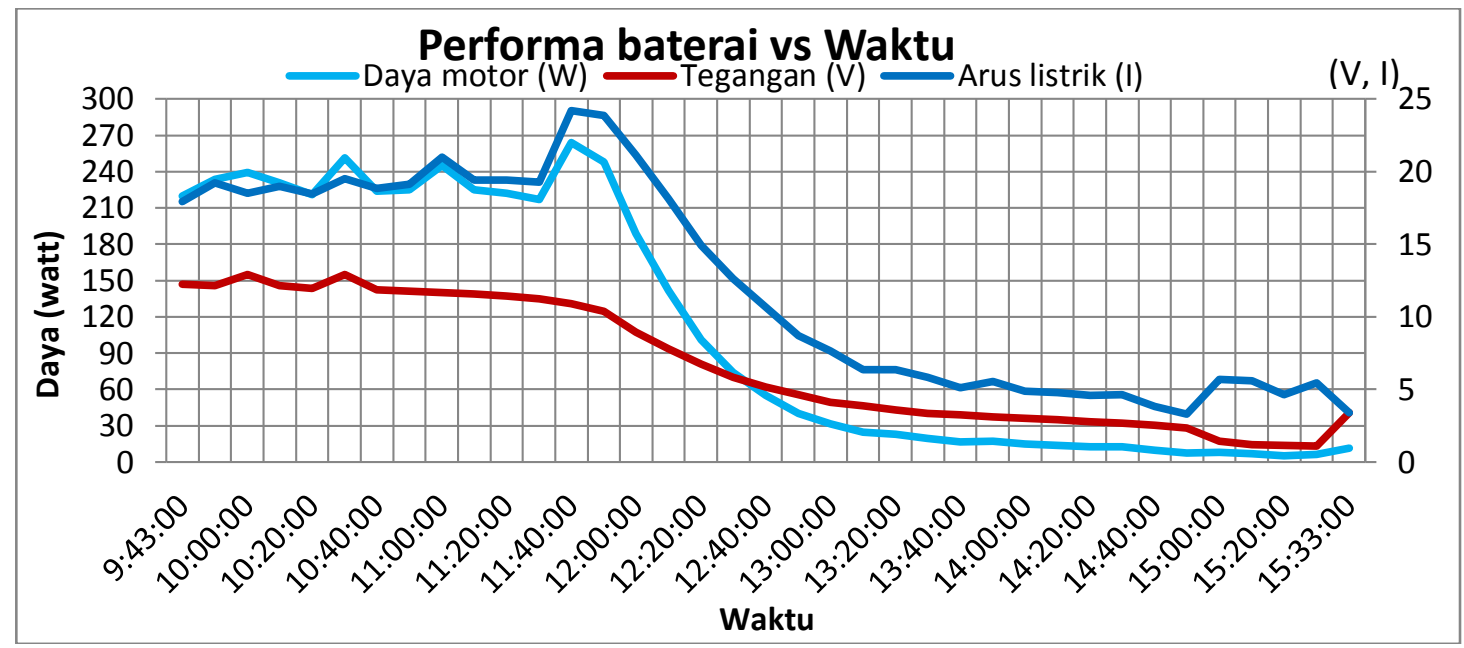

Gambar 9. Grafik keluaran daya motor pada baling-baling no. 3

Figure 9. Motor power output (watts) propeller no.3

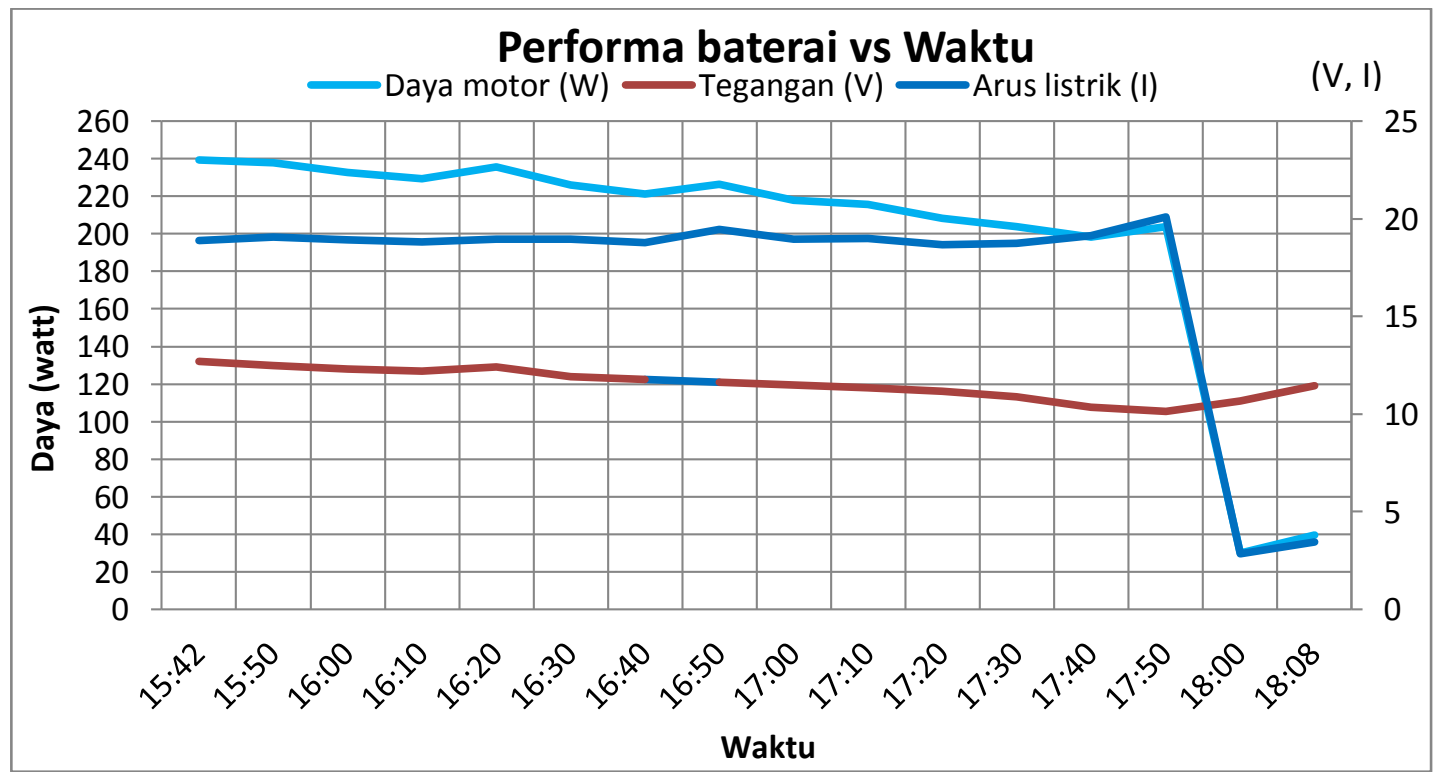

Gambar 10. Grafik keluaran daya motor pada baling-baling no. 4

Figure 10. Motor power output (watts) propeller no. 4 


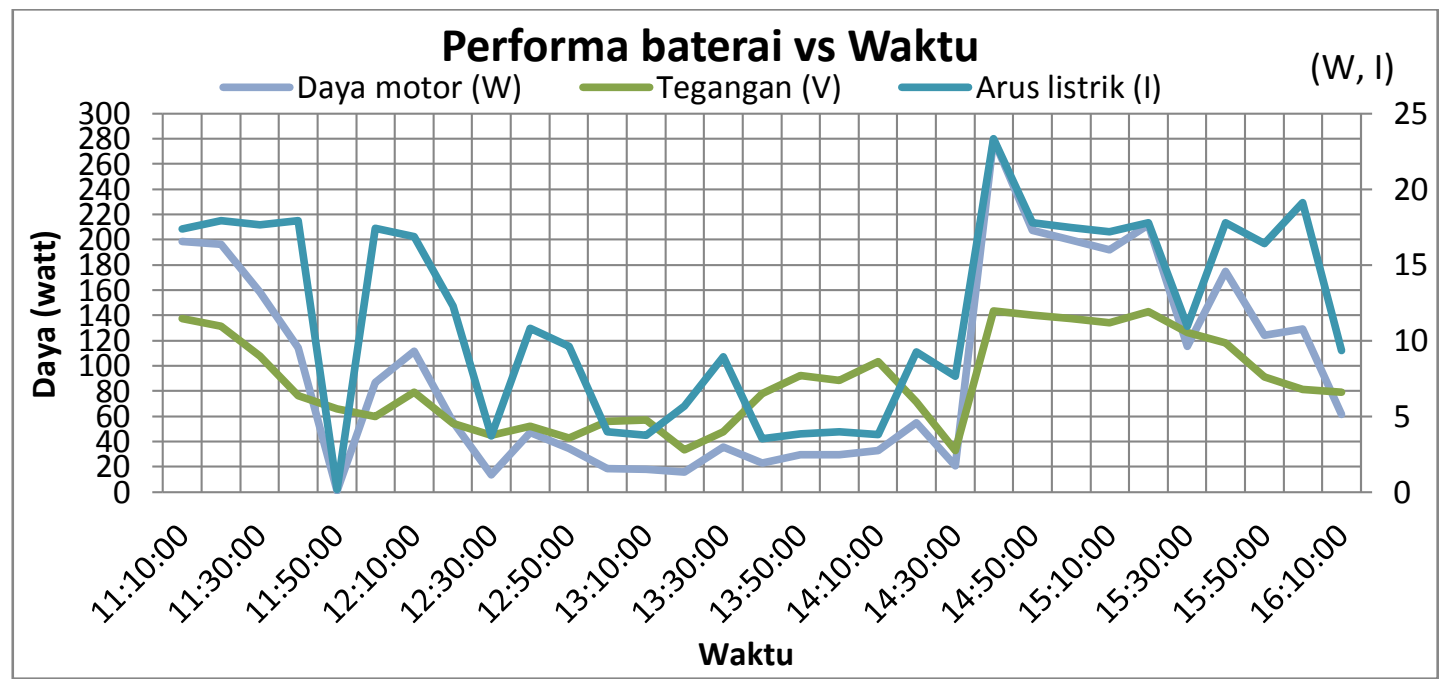

Gambar 11. Grafik keluaran daya motor pada baling-baling no. 5

Figure 11. Motor power output (watts) propeller no.5

Grafik pengujian kolam dapat dilihat bahwa semakin tinggi beban maka energi yang harus dibangkitkan juga harus lebih besar. Akibatnya, arus listrik yang disedot juga ikut meningkat. Dengan meningkatnya konsumsi arus listrik, discharge baterai menjadi lebih cepat. Hal ini terlihat dari baling-baling 1 dengan diameter lebih kecil membutuhkan waktu 3 jam 40 menit berkurang menjadi 5 jam 30 menit pada balingbaling 2, dan 3 jam 17 menit pada baling-baling 3, 3 jam 18 menit pada baling-baling 4 dan untuk baling-baling nomor 5 arus listrik mengalami fluktuasi tidak teratur.

Kondisi baling-baling nomor 5 diperkirakan terjadi karena sedotan arus yang terlalu besar akibat diameter baling-baling yang terlalu besar (beban yang terlalu besar) dan baterai yang tidak sesuai untuk sedotan arus besar secara tiba-tiba dan kemungkinan terjadi overheat yang menyebabkan motor listrik turun tegangan secara otomatis. Tampak pada grafik gambar 11 pada pukul 14.40 putaran motor kembali normal. Kondisi ini sangat mempengaruhi laju kapal nantinya.

Meskipun kondisi di laut akan jauh berbeda karena hambatan gelombang yang semakin besar, namun pengujian di kolam adalah sebagai hasil acuan untuk mengambil keputusan jumlah baterai.
Diketahui bahwa antara motor dan baling-baling memiliki kesesuaian yang khusus atau biasa disebut engine propeller matching (EPM) yaitu berkaitan dengan efisiensi keseluruhan sistem. Pada ketiga harga variasi baling-baling terlihat bahwa hampir pada keseluruhan pembebanan kondisi motor saat dicelupkan ke air mengalami fluktuasi. Pada diameter baling-baling yang semakin besar terjadi penurunan efisiensi ditunjukkan dengan RPM yang turun drastis melebihi RPM motor yang disyaratkan yakni 1300 agar tercapai kecepatan perahu yang diinginkan. Adapun penurunan efisiensi yang paling mendekati adalah baling-baling nomor 3. Baling-baling nomor 1 dan 2 meskipun menghasilkan RPM yang besar namun dari sisi torsi (ditunjukkan dengan tekanan arus olakan air di belakang baling-baling) dianggap tidak memenuhi. Sedangkan balingbaling nomor 4 dan 5 memiliki kelemahan dari RPM yang dihasilkan sehingga dianggap tidak memenuhi kecepatan perahu.

Dari uraian diatas, untuk baling-baling nomor 3 jika dirata-ratakan tiap 10 menit, kapasitas aki berkurang 1 Volt maka dalam waktu 1 jam aki akan berkurang 6 Volt.

Bagaimana menentukan jumlah kebutuhan baterai selama 8 jam operasi? Diketahui bahwa, di dalam 
pengujian kolam menggunakan baterai 1 buah dengan daya 12 Volt dan $100 \mathrm{Ah}$, maka baterai perlu dirangkai secara seri untuk memperoleh Amper-Jam yang berlimpah.

Jika disimulasikan sebagai berikut:

Diketahui:

Jika jumlah baterai 6 buah x100Ah

Baterai dihubungkan seri maka menjadi 3 set terdiri dari 2 buah aki $100 \mathrm{Ah} / 12 \mathrm{~V}$ dihubungkan seri. Hubungan seri menyebabkan Ampere (I) tetap sedangkan Tegangan (V) menjadi dua kalinya, sehingga dari 6 buah baterai menjadi 3 set.

$(3 \times 100 \mathrm{Ah}) \times 24 \mathrm{~V}=300 \mathrm{Ah} \times 24 \mathrm{~V}$

Amper (I) baterai menjadi 300Ah

Pengertian daripada baterai 100Ah adalah kemampuan baterai untuk menyuplai arus listrik ke beban utama motor DC sebesar 100 Amper dalam 1 jam.

Diketahui dari data uji kolam, untuk baling-baling nomor 3, arus listrik (I) terbesar yang disedot (discharge) hingga baterai mencapai $70 \%$ adalah pada pukul 12.10 yaitu 24 Ampere, sehingga jika diasumsikan perahu bergerak pada putaran maksimumnya (1300 RPM), dan arus listriknya tetap maka:

300Ah $/ 24 \mathrm{~A}=12,5 \mathrm{jam}$

Diketahui bahwa waktu yang dibutuhkan untuk melakukan sekali operasi perahu pulang hari adalah 8 jam, maka dapat dikatakan komposisi baterai dapat dipakai untuk tipe baling-baling nomor 3, nilai ini lebih rendah daripada nilai yang dihasilkan pada persamaan (1).

Sehingga secara hitungan maxsurf perahu dikategorikan memiliki kecepatan antara 4 dan 5 knot saja atau jarak maksimum yang dapat dijangkau sebesar

$$
\begin{aligned}
\mathrm{S} & =\mathrm{V} \times \mathrm{t} \ldots \ldots . .(3) \\
& =5(\mathrm{knot}) \times 8(\mathrm{jam}) \\
& =5(1,15 \mathrm{mil} / \mathrm{jam}) \times 8(\mathrm{jam}) \\
\mathrm{S} & =46 \mathrm{mil}
\end{aligned}
$$

\section{KESIMPULAN DAN SARAN}

1. Teknologi motor DC dapat menjadi alternatif dalam mengatasi permasalahan nelayan terhadap BBM.
2. Penggunaan Motor DC dapat diaplikasi pada perahu-perahu pulang hari dengan baik.

3. Laju penurunan tegangan baterai saat uji kolam terhadap 5 variasi baling-baling telah dilakukan dan baling-baling nomor 3 yang paling mungkin dipakai dengan komposisi baterai 6 buah kapasitas 100 Ah dirangkai seri, adalah 1 Volt tiap 10 menit pada 1300 RPM. Sehingga pada 1 jam pengoperasian motor listrik pada pengambilan data tegangan baterai berkurang 6 Volt.

4. Penurunan tegangan baterai yang cukup tajam disebabkan: baterai terlalu lama disedot (discharge) hingga melebihi batas DOD nya, dan tipe baterai adalah bukan deep cycle yang tidak sesuai karakteristik kerja motor DC yang tinggi sedotan arus listriknya pada putaran maksimum.

5. Jarak total yang dapat ditempuh untuk pergipulang perahu adalah 46 mil, melebihi jarak yang biasa ditempuh untuk perahu pulang hari yaitu 24 mil.

6. Komposisi baterai aman dibebani motor listrik selama 8 jam rata-rata pengoperasian perahu pulang hari.

7. Pengoperasian motor yang lebih lama dapat diperoleh pada kecepatan kapal yang rendah.

8. Sebaiknya sebelum mengoperasikan kapal, aki dalam kondisi penuh.

\section{DAFTAR PUSTAKA}

Adjie, S. W. 2009. Engine Propeller Matching. Bahan Ajar Mata Kuliah EPM, Pasca Sarjana, Program Studi Teknologi Kelautan ITS, halaman 6.

Daniel, D., H. Candra, A. Ferlin, Muhammad dan H. Kretiawan. 2007. Optimalisasi Kapal Nelayan Tradisional di Sumatera, Jawa, Bali, dan Sulawesi Selatan. Laporan Akhir Penelitian. Pusat Riset Teknologi Kelautan.

Daniel, D., I. Pratama dan H. Candra. 2011. Rancang Bangun Kapal Pemantau Perairan Tenaga Matahari. Laporan Akhir Riset. P3TKP Balitbang KP 2011

Daniel, D. 2011. Aplikasi Sel Surya (photovoltaic cells) pada Kapal Katamaran Tenaga Matahari. Jurnal Kelautan Nasional Vol. 7 No. 2 Agustus 2011. 
MIT Electric Vehicle Team. 2008. A Guide to Understanding Battery Specifications.

Murdijanto. 2005. Diktat Motor Penggerak Kapal dan Mesin Bantu. Jurusan Teknik Perkapalan, ITS, Surabaya.

Musta'in, M. 2009. Analisis Teknis Perancangan Floating Recharge untuk Kapal Nelayan di Daerah Cilacap. Master thesis., Program Pascasarjana Program Studi Teknologi Kelautan, ITS.

Sadiku, 2009. Fundamentals of Electric Circuits 4th Ed. Mc Graw Hill.

Sadiku, M.N.O. dan C.K. Alexander. 2008. Korelasi Antara Kedalaman Sedimen di Pelabuhan Benoa dan Konsentrasi Logam Berat $\mathrm{Pb}$ dan $\mathrm{Cu}$. Jurnal Kimia. Jurusan Kimia FMIPA Universitas Udayana, Bukit Jimbaran. ISSN 1907-9850.

Sudiyono, S. dan B. Antoko. 2008. Perancangan dan Pembuatan Kapal Wisata dengan Motor Generator Listrik Tenaga Surya Sebagai Energi Alternatif Penggerak Propeler. Jurnal Teknik Mesin Vol. 10 No. 1, April 2008: 5262.

Togan, P. 2010. Perencanaan Sistem Penyimpanan Energi dengan Menggunakan Battery pada Pembangkit Listrik Tenaga Arus Laut (PLTAL) di Desa Ketapang, Kabupaten Lombok Timur, NTB. Tesis. Jurusan Teknik Elektro, ITS, Surabaya. 